Copyright (C) 2020 University of Bucharest Printed in Romania. All rights reserved

ISSN print: $1224-5984$

ISSN online: $2248-3942$
Rom Biotechnol Lett. 2020; 25(5): 1908-1914

doi: $10.25083 / \mathrm{rbl} / 25.5 / 1908.1914$

\title{
Extracellular enzymatic activities in the aquatic ecosystems of the Danube Delta. 1. B-Glucosidase activity
}

\author{
IOAN PĂCEȘILĂ ${ }^{1 *}$
}

${ }^{1}$ Institute of Biology, Romanian Academy, 296 Splaiul Independentei, 060031, Bucharest, Romania

\begin{abstract}
Extracellular enzymatic hydrolysis is the first step in mineralization of the most macromolecules present in detrital organic matter composition. $\beta$-glucosidase (GLC) is an extracellular enzyme responsible for catalysis of cleavage of $\beta$ 1-4 glycosidic bonds between two adjacent glucose molecules. It is synthesized by various heterotrophic microorganisms from aquatic and terrestrial ecosystems, and, also, is a component of cellulolytic system. GLC can represent a model enzyme for the studding microbial decomposition process of carbohydrates from natural ecosystems. The aim of the present paper is to describe some aspects of GLC spatial and temporal dynamics, investigated in water and sediment of several aquatic ecosystems of Danube Delta, during 2011-2013 interval: Roșu Lake, Mândra Lake and two adjacent channels, Roșu - Împuțita Channel and Roșu - Puiu Channel. In the studied period, the highest activity of the GLC was recorded at the water-sediment interface; maximum value (20137 nmol p-nitrophenol g-1 h-1) was reached in October 2013 in Roşu Lake. For seasonal and annual dynamics of GLC activity, the water and sediment samples had shown high similarity tendencies. The ecosystem where the average GLC activity was higher in the research period was Roșu - Împuțita Channel. Statistical analysis methods (hierarchical cluster, NMDS and one way ANOVA) were used to evaluate the similarity of data series from different ecosystems and areas.
\end{abstract}

Keywords $\quad \beta$-glucosidase, extracellular enzymatic activity, Danube Delta.

To cite this article: PĂCEŞILĂ I. Extracellular enzymatic activities in the aquatic ecosystems of the Danube Delta. 1. $\beta$-Glucosidase activity. Rom Biotechnol Lett. 2020; 25(5): 1908-1914. DOI: $10.25083 / \mathrm{rbl} / 25.5 / 1908.1914$

*Corresponding author: IOAN PĂCEŞILĂ, Institute of Biology, Romanian Academy, 296 Splaiul Independentei, 060031, Bucharest, Romania, POBox 56-53, Phone + 4021 2219202, Fax + 40212219071

E-mail: ioan.pacesila@gmail.com 


\section{Introduction}

The decomposition process of natural detrital organic matter requires, in most of the cases, the activity of extracellular enzymes. These enzymes act as depolymerisators by catalyzing the dissociation of the organic large macromolecules into smaller ones, available to heterotrophic microbial cells. A large diversity of organic macromolecules with different compositions, including refractory ones to mineralization processes, is frequently present in nature. Consequently, heterotrophic microorganisms, the main users of detrital organic matter in natural ecosystems, synthesize a wide range of extracellular enzymes, with various mechanisms of action and different specificities, able to catalyses the breakdown of complex organic products in simpler compounds that can be used in microbial metabolic pathways (CHRÓSt [1]; ZARNEA [2]; MUDRYK \& SKÓRCZEWSKI [3]; ISOBE \& OHTE [4]).

Cellulose is an organic macromolecule with the polymeric structure. It is composed of linear and unbranched chains of glucose molecules linked by $\beta$ 1,4-glycosidic bonds. Its structural unit is cellobiose, a glucose dimmer (KAUR \& al [5]). It is considered the most abundant organic molecule in nature, being present in the cell wall of green plants and several algae species, but is, also, synthesized by some categories of bacteria and protozoa (BITTON [6]; ZARNEA \& POPESCU [7]). Nowadays, cellulose is widely used in different sectors of industry, including paper, textiles and biofuels ones (CARROLL \& SOMERVILLE [8]; KIHLMAN [9]). It is, also, an important part of domestic waste and vegetable, representing a potential source of renewable energy and raw materials (KAUR et al [5]). Enzymatic hydrolysis of cellulose, followed by alcoholic fermentation, is a potential method for the production of alternative fuels destined to transport vehicles (TEUGJASAND \& VÄLJAMÄE [10]).

There are over two hundred known species of microorganisms (bacteria, actinomycetes, microfungi, protozoa etc.) that synthesizes cellulolytic enzymes and, then, have the ability to degrade cellulose (ZARNEA [2]). Enzymatic hydrolysis of cellulose requires three types of enzymes with sinergically activity: endoglucanase, cellobiase and GLC. The appropriate ratio of each enzyme is crucial for an efficient hydrolysis. Endo- $\beta$-glucanases (E.C. 3.2.1.4.) are enzymes with moderate specificity that break-down, in a randomized way, the internal $\beta-1,4$ glycosidic bonds from the structure of cellulose macromolecules. Cellobiohydrolases (EC 3.2.1.91) acts on nonreducing end of cellulosic chains and release cellobiose, and then, GLC (EC 3.2.121) catalyses the hydrolysis of cellobiose to glucose, an important source of carbon and energy for many organisms, including microorganisms. Cellobiose in a strong repressor of cellobiohidrolases and endo- $\beta$-glucanases, and the GLC activity decrease its effect. But the accumulation in excess of glucose has an inhibitor effect on GLC activity and, in this case, cellobiose production will increase. The inhibition process of GLC is transglycosylation reaction that competes with 5cellobiose hydrolysis (CHAUVE \& al [11]; KAUR \& al [5]; TEUGJAS \& VÄLJAMÄE [10]). GLC activity is not repressed only by the presence of glucose in the reaction medium (PANDEY \& al [12]) but, also, by the presence of heavy metals like copper. Some studies have shown that decaying plant residues lose GLC activity if they are subject of pollution with heavy metals (JOACHIM \& al [13]). GLC, in general, is the most easily detected of the three enzymes involved in cellulose degradation and has an essential role in the carbon cycle (STEGE \& al [14]). It is frequently used as a model enzyme for the studding microbial decomposition process of carbohydrates from natural ecosystems (SIECZKO \& al [15]). Nowadays, applied biotechnology industry shows an increasing interest in GLC usage in biotechnological processes, such as the production of biofuels from lignocellulosic materials, that involve the use of the cellulosolitic enzymatic complex (TIWARI \& al [16]). Biofuels can represent a potential alternative energy source to fossil fuels (HASSAN \& KALAM [17]). The development of biotechnology industries will lead, certainly, to a more varied usage of this enzyme.

This paper presents some characteristics of spatiotemporal dynamics of GLC activity in the water column and the sediments of several lotic and lentic aquatic ecosystems of the Danube Delta.

\section{Materials and Metods}

Water and sediment samples were collected from eight sampling stations, three times per year, during May, July and October, from 2011 to 2013 (Fig. 1): five stations $\left(\mathrm{R}_{1}-\mathrm{R}_{5}\right)$ in Roșu Lake, the youngest and the largest aquatic ecosystem from fluvio-deltaic complex, one station (M) in Mândra Lake, a low depth meso-europhic aquatic ecosystem (PARPALA \& ZINEVICI [18]), one stationin Roşu - Împuţita channel $\left(\mathrm{C}_{1}\right)$ and, also, one station in 
Roşu - Puiu channel $\left(\mathrm{C}_{2}\right)$. The intensity of $\beta$-glucosidase activity was evaluated through estimation of substrate consumption method (OBST [19]). The used substrate was p-nitrophenyl- $\beta$-D-glucopyranoside.
Statistical analyses were performed using the Paleontological Statistics (PAST) software (HAMMER \& al [20]). All variables were $\ln (\mathrm{x})$ transformed.

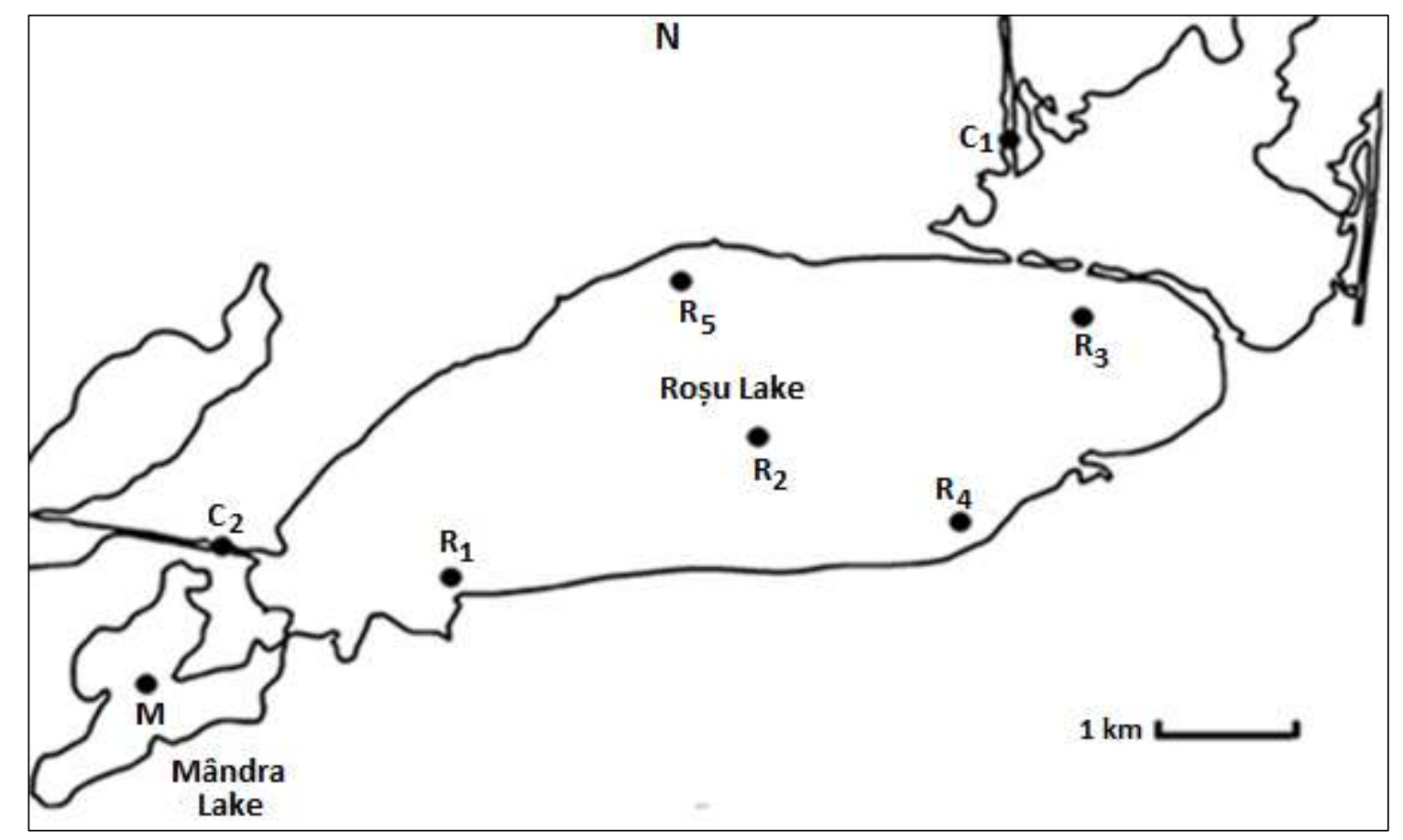

Figure 1. Location of sampling stations: Roşu Lake (R), Mândra Lake (M), Roşu - Împuţita Channel (C) and Roşu - Puiu Channel (C2) (PĂCEŞILĂ [21]).

\section{Results and Discussion}

The dynamics of GLC in water and sediments, in this study, reveals the constant presence of glucose polymers, like cellulose, in the structure of detrital organic matter of investigating ecosystems.

In the water column GLC activity varied between 114 and 2092 nmol p-nitrophenol $\mathrm{L}^{-1} \mathrm{~h}^{-1}$. In Roșu Lake the maximum average value was recorded in $\mathrm{R}_{5}(1080 \mathrm{nmol}$ p-nitrophenol $\left.\mathrm{L}^{-1} \mathrm{~h}^{-1}\right)$ while the minimum average value was recorded in $\mathrm{R}_{2}$ (366 nmol p-nitrofenol $\mathrm{L}^{-1} \mathrm{~h}^{-1}$ ). Among all studied ecosystems GLC was higher in Roşu - Împuţita Channel (average value: 1034 nmol p-nitrophenol $\mathrm{L}^{-1} \mathrm{~h}^{-1}$ ) and lower in Mândra Lake (average value: $771 \mathrm{nmol}$ p-nitrophenol $\mathrm{L}^{-1} \mathrm{~h}^{-1}$ ) although in this ecosystem, in the same period, the total microbial biomass have shown the highest values in both water and sediment (PĂCEȘILĂ [21]).

The GLC activity in sediment was, generally, higher than in water column. In sediment GLC had a large variation of activity over the three years of investigation, its values ranging within 2036-20137 nmol p-nitrophenol $\mathrm{g}^{-1} \mathrm{~h}^{-1}$ interval. The sediments of inland waters are a complex medium with a large ecological importance, composed of mineral particles, inorganic compounds with biogenic origin and detrital organic matter in different stage of decomposition. In many ecosystems the sediments are the main level where mineralization processes occur. The most active area of sediment is the superficial level, at the watersediment interface. Here, the microbial metabolic activity is higher than the superior level of water column, but are significantly decreasing the lower level of sediment. In lentic ecosystems, in many cases, the composition of the microbiota and the intensity of microbial metabolic processes are positively related with the rates of sedimentation processes of organic matter particles from the water column (ZARNEA [2]; WETZEL [22]; PLOUG \& GOSSART [23]; GOSSART \& PLOUG [24]). 
a)
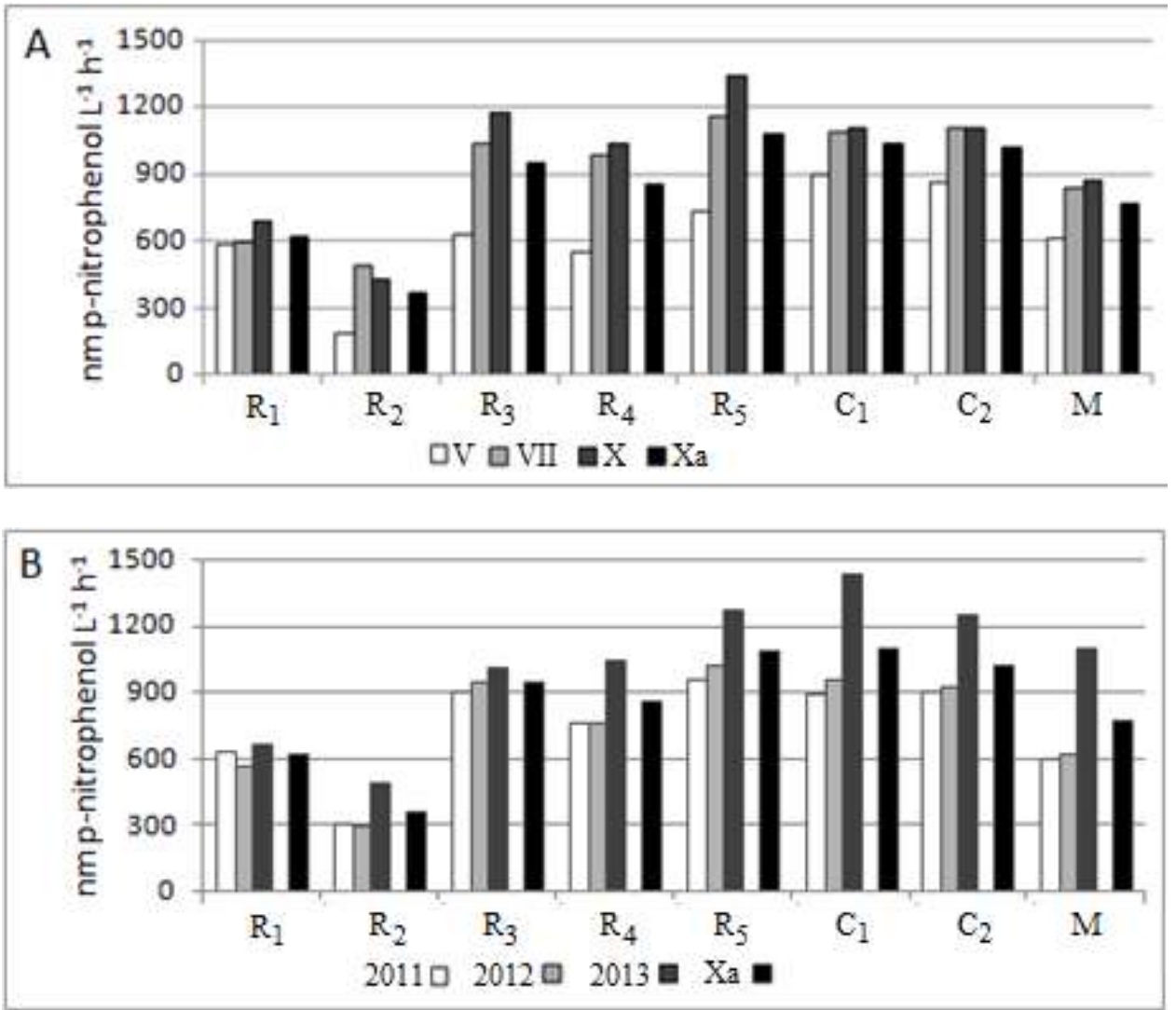

b)
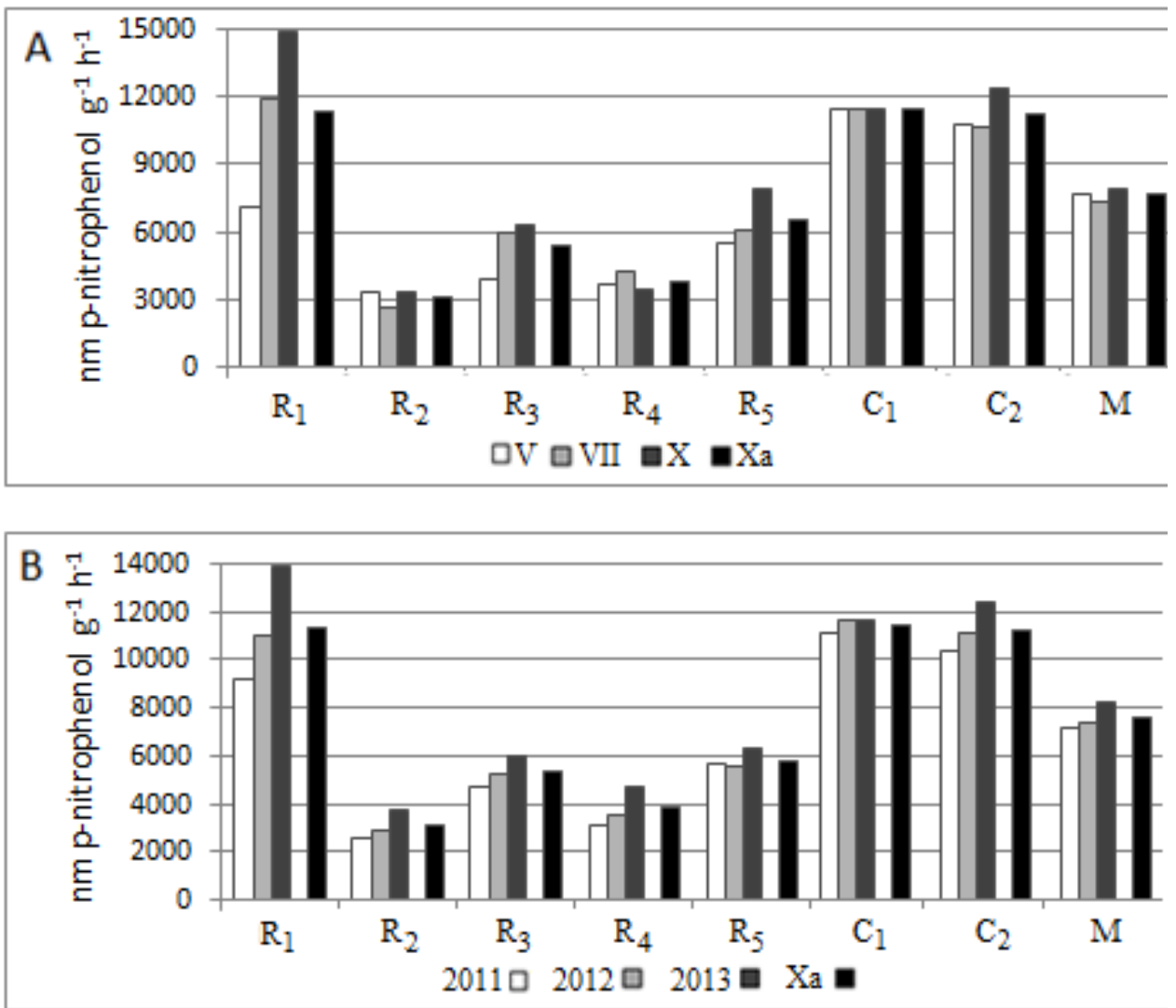

Figure 2. Seasonal (A) and annual (B) dynamics of $\beta$-GLC in water columnn (a) and sediment $(\mathbf{b})$. 
The GLC activity values in sediment were highest in Roşu - Împuţita Channel (average value: 11393 nmol p-nitrophenol $\mathrm{g}^{-1} \mathrm{~h}^{-1}$ ) and lowest in the Roșu Lake (average value for entire lake: $\left.5981 \mathrm{nmol} \mathrm{p-nitrofenol} \mathrm{g}^{-1} \mathrm{~h}^{-1}\right)$. In contrast with the water column, in Roșu Lake sediments, GLC activity recorded maximum value in $\mathrm{R}_{1}$ (average value: 11240 nmol $\mathrm{p}$-nitrophenol $\mathrm{g}^{-1} \mathrm{~h}^{-1}$ ) while minimum values was shown in $R_{2}$ (average value: $3070 \mathrm{nmol}$ p-nitrophenol $\left.\mathrm{g}^{-1} \mathrm{~h}^{-1}\right)$.

In both water column and sediment, during the research period, Roșu Lake has shown a large spatial heterogeneity. Lake Roşu is the largest lake $\left(14,5 \mathrm{~km}^{2}\right)$ from the fluvial-maritime delta complex. At its level signs of eutrophication processes occur, especially intense cyanobacterial blooms episodes, (MOLDOVEANU \&
FLORESCU [25]), while submerged vegetation appears only sporadically (SÂRBU [26]). The differences revealed between different areas of Roșu Lake can be a consequence of spatial heterogeneity, encountered in large shallow lakes. Spatial heterogeneity of terrestrial and aquatic ecosystems is a result of interactions between physical, chemical and biological parameters. In the cases of aquatic ecosystems, water movements, generated by wind, gravity and density differences in water masses, have an important contribution in nutrient and food distribution, and, therefore, in the spatial dynamics of various types of aquatic organisms (WETZEL [22]). Water currents, in many cases, resuspended organic matter particles, microorganisms and alegaes cells from sediments (ZARNEA [2]; MIYAJIMA \& al [27]).
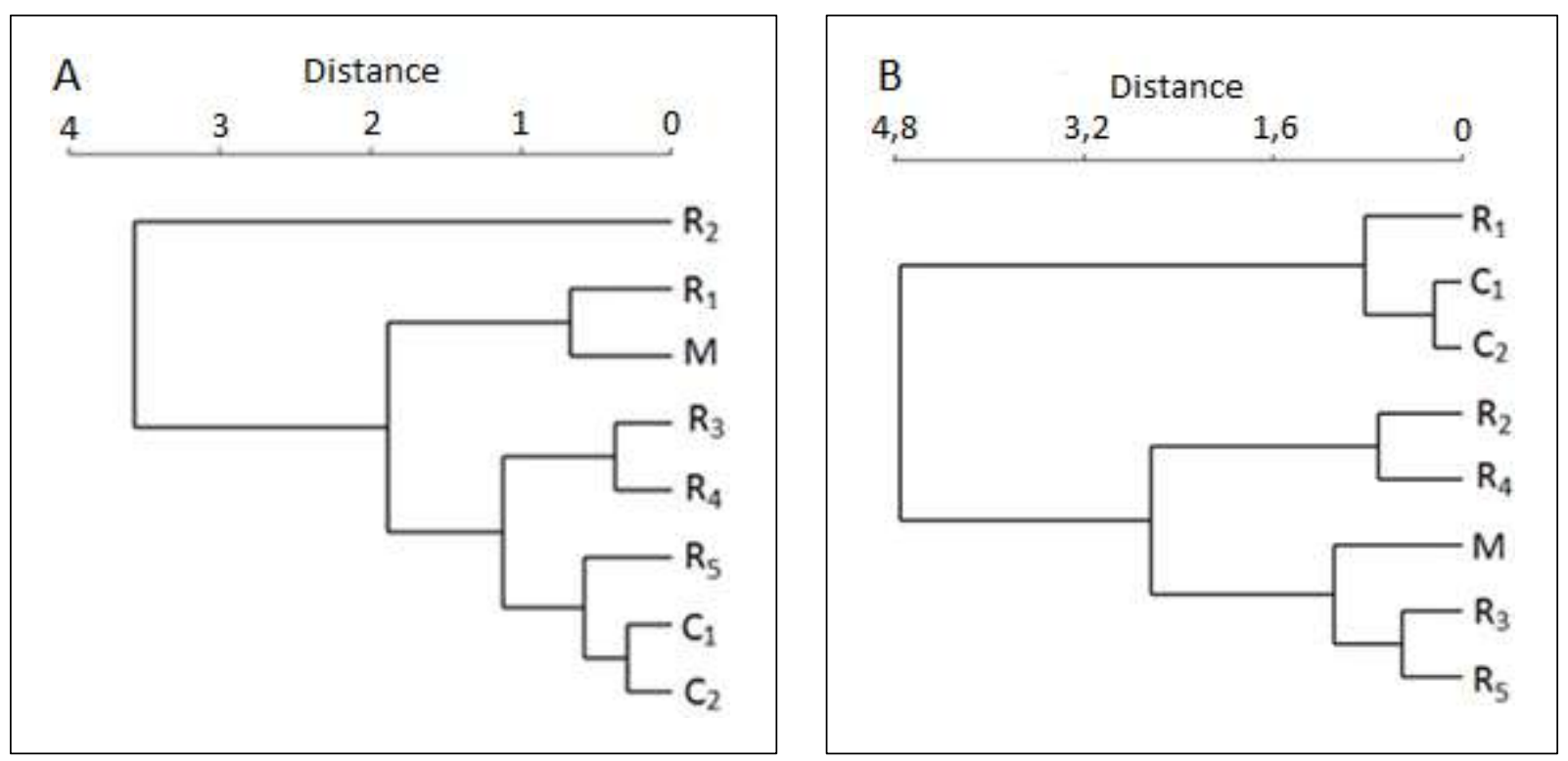

Figure 3. The similarity (Ward's method) of the studied areas based on $\beta$ GLC dynamics in water column $(\mathbf{A})$ and sediment $(\mathbf{B})$.

Using hierarchical cluster analysis, Ward method, the similarities between GLC activity dynamics from sampling areas were evaluated (Fig. 3). In the water column (Fig. 3A) high similarities were found between $\mathrm{R}_{3}$ and $\mathrm{R}_{4}$ and, also, between the stations from loctic ecosystems, $\mathrm{C}_{1}$ and $\mathrm{C}_{2}$. In Roşu Lake values recorded in $\mathrm{R}_{2}$, a sampling station located around the center of the basin, show a different grouping from the other data series, obtained from the sampling stations located near the shores. Instead, $\mathrm{R}_{1}$ was more similar to $\mathrm{M}$ than any other stations from Roșu Lake. In the sediment, the grouping of sampling stations it was, in most of the cases, different from the water column (Fig. 3B). In contrast with the water column, $\mathrm{R}_{2}$ are no longer grouping separately from the other sampling stations from Roșu Lake. Instead, the variation pattern of GLC activity in this station was similar with $\mathrm{R}_{4}$. High similarity was, also, shown between $\mathrm{R}_{3}$ and $\mathrm{R}_{5}$, and, like water column, between $\mathrm{C}_{1}$ and $\mathrm{C}_{2}$. 

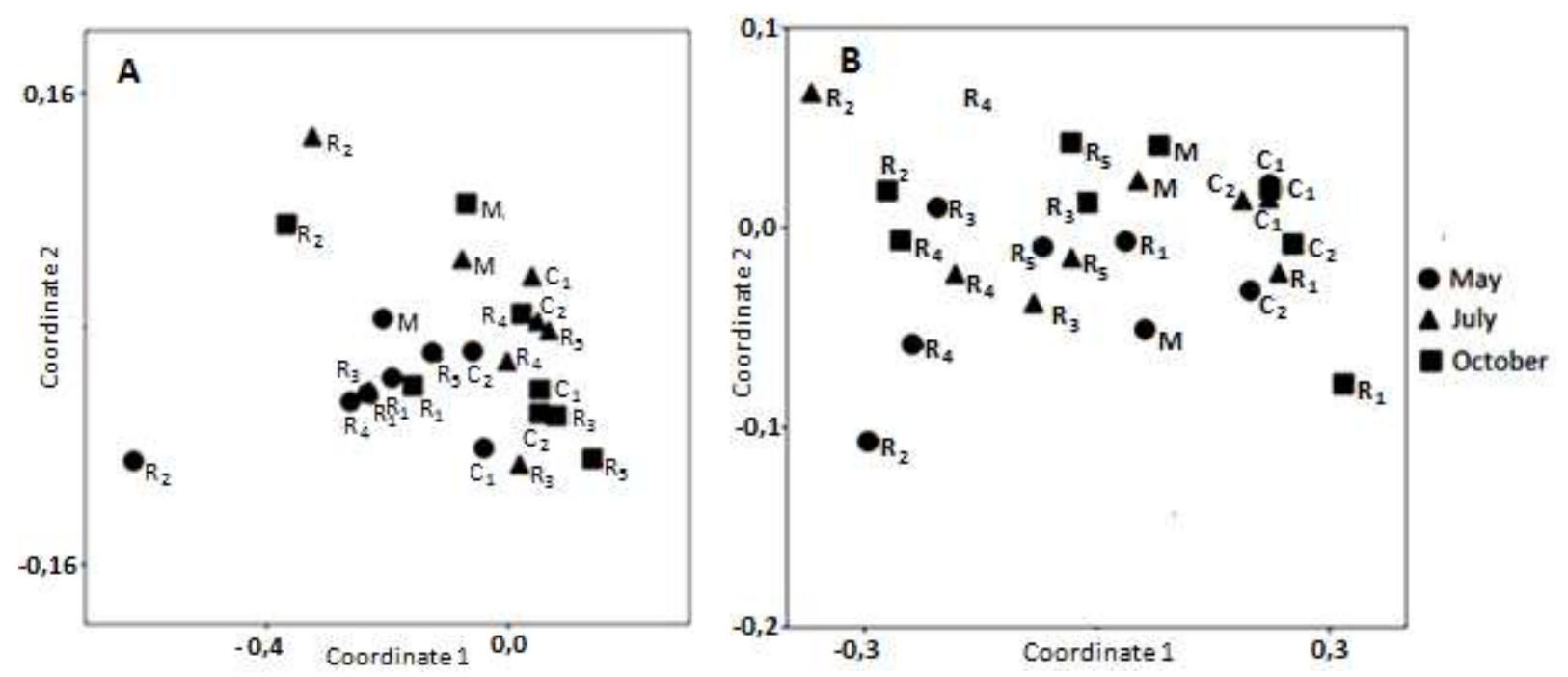

Figure 4. Nonmetric multidimensional scalling (NMDS) of $\beta$ GLC seasonal values in water column $(\mathbf{A})$ and sediment $(\mathbf{B})$.

GLC activity was most intense, in almost cases, in Octomber and less intense in May in both water and sediment (Fig. 2a and Fig. 2b). In general, GLC activity show highest values in autumn, when massive death of vegetation and phytoplanktonic organisms lead to releasing in the medium of large quantities of polizaharidic compounds (CHRÓST \& OVERBECK [28]; NICOLESCU \& al [29]). Maximum seasonal average values were recorded in $\mathrm{R}_{5}\left(1345 \mathrm{nmol} \mathrm{p}\right.$-nitrophenol $\left.\mathrm{L}^{-1} \mathrm{~h}^{-1}\right)$ in the water column and in $\mathrm{R}_{1}\left(14830 \mathrm{nmol} \mathrm{p}\right.$-nitrophenol $\left.\mathrm{g}^{-1} \mathrm{~h}^{-1}\right)$ in the sediment. In order to assess the differences between seasons and sampling sites NMDS was used (Fig. 4). Although the intensity of GLC activity from water and sediment showed a wide fluctuation, it has not revealed a clear grouping of data basis on spatial or temporal criteria. Some seasonal and spatial tendencies of association can be observed, but a general pattern of data arrangement has not identified. The differences between seasonal dynamics of GLC activity were evaluated using one way ANOVA method. The results show no significant differences between the three seasons in both water column $(n=24 ; p=0,26 ; F=1,43)$ and in sediment $(n=24 ; p=0,35 ; F=1,07)$.

Annual dynamic (Fig. 2B) of GLC activity was characterized by high values in 2013 and low values in 2011 for in both water column and sediment. Maximum annual average value reached in the water column was 1429 nmol p-nitrophenol $\mathrm{L}^{-1} \mathrm{~h}^{-1}$, in $\mathrm{C} 2$, 2013, while in sediment was $13812 \mathrm{nmol} \mathrm{p-nitrophenol} \mathrm{g}^{-1} \mathrm{~h}^{-1}$, in R1, 2013.

\section{Conclusion}

GLC was active for entirely research period in both water column and sediment of all evaluated ecosystems, suggesting that glucose polymers, like cellulose, are a regular component of their detrital organic matter. Highest values of the intensity of GLC catalytic activity were founded, in most of the cases, in sediment, but wide spatial and temporal variations were revealed in both types of samples. Roșu - Împuțita Channel ecosystem had shown the most intense activity of this enzyme at both water and sediment level; instead, in the lentic ecosystems, Mândra Lake and Roșu Lake, GLC activity recorded lowest intensity. In Roșu Lake GLC activity was characterized by high differences recorded between sampling sites, most probable due high spatial heterogeneity of this ecosystem. The lowest variation in intensity of GLC activity was shown in lotic ecosystems. Groping of sampling sites by similarity through cluster analysis, Ward method, reveled highest similarity between $\mathrm{C} 1$ and $\mathrm{C} 2$ in both water and sediment.

In all ecosystems GLC was most active, in general, in the autumn season, when large quantities of polizaharidic compounds originated from death vegetation and phytoplanktonic compounds were released in the medium, while the lowest activity of this enzyme was recorded in spring season. Two statistical analyses, ANOVA and NMDS, have shown no differences between data series obtained from the three seasons evaluated during the research project. Annual dynamics of GLC activity recorded highest annual average values in 2013 for all ecosystems at both water column ad sediment levels.

\section{Acknowledgment}

This study was funded by the project no. RO1567IBB02/2017 from the Institute of Biology of Romanian Academy, Bucharest. 


\section{References}

1. R.J. CHRÓST. Environmental control of the synthesis and activity of aquatic microbial ectoenzymes. In: CHRÓST RJ (ed.), Microbial enzymes in aquatic environments, New York: Springer-Verlag (1991).

2. G. ZARNEA. Tratat de microbiologie generală, vol. V, eds. of Romanian Academy, Bucharest, 1994, pp. 684-694.

3. Z.J. MUDRYK, P. SKÓRCZEWSKI. Enzymatic activity and degradation of organic macromolecules by neustonic and planktonic bacteria in an estuarine lake, Pol. J. Ecol., 54: 3, 14 (2006).

4. K. ISOBE, N. ANDOHTE. Ecological perspectives on microbes involvedin N-cycling, Microbes Environ., 29: 4, 16 (2014).

5. J. KAUR, B.S. CHADHA, B.A. KUMAR. Purification and characterization of $\beta$-glucosidase from Melanocarpus sp. MTCC 3922, Electron J. Biotechnol, 10: 260,70 (2007).

6. G. BITTON, Wastewater microbiology, Edit. WileyLiss, New York, 2005, pp. 153-172.

7. G. ZARNEA, O. POPESCU. Dicționar de microbiologie generală şi biologie molecular, Edit. Academiei Române, București, 2012, 1331 pp.

8. A. CARROLL, C. SOMERVILLE. Cellulosic biofuels, Ann. Rev. Plant. Biol., 60: 165,182 (2009).

9. M. KIHLMAN, Dissolution of cellulose for textile fibre applications, Lic.-avh. Facculty fo Technology and Science, 2012, Karlstad Universitet, 60 pp.

10. H. TEUGJAS, P. VÄLJAMÄE. Selecting $\beta$-glucosidases to support cellulases in cellulose saccharification, Biotechnol Biofuels, 6(1):105 (2013).

11. M. CHAUVE, H. MATHIS, D. HUC, D. CASANAVE, F. MONOT, N. FERREIRA. Comparative kinetic analysis of two fungal beta-glucosidases, Biotechnol. Biofuels, 20(3): 3 (2010).

12. S. PANDEY, A. SREE, S.S. DASH, D.P. SETHI. A novel method for screening beta-glucosidase inhibitors, BMC Microbiol., 13: 55 (2013).

13. H.J.R. JOACHIM, MAKOI \& PATRICK A. NDAKIDEMI. Selected soil enzymes: Examples of their potential roles in the ecosystem, African Journal of Biotechnology, 7 (3): 181, 191 (2008).

14. P.W. STEGE, G.A. MESSINA, G. BIANCHI, R.A. OLSINA, J. RABA. Determination of b-glucosidase activity in soils with a bioanalytical sensor modified with multiwalled carbon nano-tubes, Anal. Bioanal. Chem., 397:1347, 1353 (2010).

15. A. SIECZKO, M. MASCHEK, P. PEDUZZI. Algal extracellular release in river-floodplain dissolved organic matter: response of extracellular enzymatic activity during a post-flood period, Frontiers in Microbiology, 17: 6, 80 (2015).
16. P. TIWARI, B.N. MISRA, N.S. SANGWAN. $\beta$-glucosidases from the fungus Trichoderma: an efficient cellulase machinery in biotechnological applications, BioMed Research International, Article ID 203735, 10 pp. (2013).

17. M.H. HASSAN, M.A. KALAM. An Overview of Biofuel as a Renewable Energy Source: Development and Challenges, Procedia Engineering, 56: 39, 53 (2013).

18. L. PARPALĂ, V. ZINEVICI. Biocenotic study on trophic state of the Danube Delta shallow lakes (Puiu and Mândra). 2. The significance of some ecological parameters of zooplankton community, Proceeding of the Inst. of Biology, 4: 121, 132, (2001).

19. U. OBST. Test instructions for measuring the microbial metabolic activity in water sample. Anal Chem, 321: 166, 168, (1985).

20. O. HAMMER, D.A. T. HARPER, P.D. RYAN. PAST: Paleontological statistics software package for education and data analysis, Palaeontologia Electronica, 4(1): 9 pp. (2001).

21. I. PĂCEȘILĂ. Benthic microbial biomass dynamics in aquatic ecosystems of the Danube Delta, Rom. Biotech. Lett., 20 (3): 10496, 10503 (2015).

22. R.G. WETZEL. Limnology: Lake and River Ecosystems, eds., Academic Press., New York, 2001, pp. 489-526, 527-575, 631-664.

23. H. PLOUG, H.P. GROSSART. Bacterial growth and grazing on diatom aggregates: respiratory carbon turnover as a function of aggregate size and sinking velocity, Limnol. Oceanogr., 45:1467, 1475 (2000).

24. H.P. GROSSART, H. PLOUG. Microbial degradation of organic carbon and nitrogen on diatom aggregates. Limnol. Oceanogr., 46: 267, 277 (2001).

25. M. MOLDOVEANU, L.I. FLORESCU. Long - term analysis of cyanobacterial blooms in Lake Roşu (Danube Delta), Oltenia. Studii şi comunicări. Ştiinţele Naturii, 29(1): 244, 251 (2013).

26. A. SÂRBU, Aquatic macrophytes, in C. TUDORANCEA \& M.M. TUDORANCEA. Danube Delta. Genesis and biodiversity, eds. Backhuys Publishers, Leiden, 2006, pp. 133-176.

27. T. MIYAJIMA, I. KOIKE, H. YAMANO, H. IIZUMI. Accumulation and transport of seagrass-derived organic matter in reef flat sediment of Green Island, Great Barrier Reef, Marine Ecology Progress Series, 175: 251, 259 (1998).

28. R.J. CHRÓST, J. OVERBECK. Substrate-ectoenzyme interaction: significance of $\beta$-glucosidase activity for glucose metabolism by aquatic bacteria, Arch. Hydrobiol. Beih. Erghebn. Limnol., 34: 93, 98 (1990).

29. D. NICOLESCU, D. IONICĂ, A. SIMON-GRUIŢĂ, C. SANDU, V GHEORDUNESCU. Microbial Degradation of the organic matter from the Danube Delta lakes. 2. Extracellular enzymatic activity, Proc. Inst. Biol., 2: 85, 90 (1999). 